\title{
Peningkatan Pemahaman Konsep Matematis Melalui Model Pembelajaran Rotating Trio Exchange (RTE)
}

\author{
Ayu Muharomah ${ }^{1}$ Farida $^{2}$, Rizki Wahyu Yunian Putra ${ }^{3}$ \\ ${ }^{1,2,3}$ Fakultas Tarbiyah dan Keguruan ,Universitas Islam Negeri Raden Intan Lampung \\ e-mail: ${ }^{1}$ Muharomahayu@ gmail.com,${ }^{2}$ farida@ radenintan.ac.id , \\ rizkiwahyuyp@radenintan.ac.id
}

\begin{abstract}
The purpose of this research is to determine whether there is an increased understanding of mathematical concepts through learning modelRotating Trio Exchange (RTE). The method used is Quasi Experiment Design. Subjects in this study were students of class VIII SMP Negeri 2 Kalianda, with a sample of two classes.This study uses statistical techniques through the Independent-Sample $t$ Test. The results of this study indicate that the Rotating Trio Exchange (RTE) learning model is better than the conventional learning model. The conclusion in this study is that there is an increase in understanding of mathematical concepts through the Rotating Trio Exchange (RTE) learning model with an increase in the average pretest and posttest results, namely 0.602 .
\end{abstract}

Keywords: Mathematical Concept Understanding Ability, Rotating Trio Exchange (RTE)

\begin{abstract}
Abstrak: Penelitian ini bertujuan untuk mengetahui apakah terdapat peningkatan pemahaman konsep matematis melalui model pembelajaran Rotating Trio Exchange (RTE). Metode yang digunakan yaitu Quasi Exsperimen Design. Subjek dalam penelitian ini adalah siswa kelas VIII SMP Negeri 2 Kalianda, dengan sampel sebanyak dua kelas. Penelitian ini menggunkan Teknik statistika melalui Independen-Sampel t Test. Hasil dari penelitian ini bahwa model pembelajaran Rotating Trio Exchange (RTE) lebih baik dari model pembelajaran konvensional. Kesimpulan dalam penelitian ini yaitu terdapat peningkatan pemahaman konsep matematis melalui model pembelajaran Rotating Trio Exchange (RTE) dengan peningkatann hasil rata-rata pretest dan posttest yaitu 0,602 .
\end{abstract}

Kata kunci: Kemampuan Pemahaman Konsep Matematis, Rotating Trio Exchange (RTE) 


\section{PENDAHULUAN}

Proses belajar selalu melekat dalam kehidupan manusia dan potensi yang dimiliki perlu adanya peningkatan. Proses belajar adalah cara yang tepat guna meningkatkan kemampuan seseorang khususnya dalam kemampuan matematis. kemampuan matematis dapat diartikan sebagai upaya memecahkan masalah. Matematika merupakan salah satu mata pelajaran yang dapat meningkatkan kemampuan matematis, meningkatkan kemampuan siswa dalam hal berfikir karena ilmu matematika mempunyai struktur yang jelas serta kuat antar konsep sehingga melatih siswa berfikir secara rasional (Rahmawati, 2017; Yunita, Juwita, \& Kartika, 2020). Selain itu, matematika juga merupakan bagian yang harus dikuasai siswa sejak Sekolah Dasar sampai Perguruan Tinggi.

Hal penting dalam pembelajaran matematika adalah pemahaman konsep matematisnya, karena jika siswa mampu memahami konsep matematis dengan baik, maka hal itu pasti akan menjadi titik dasar bahwa siswa akan mudah memahami dan menyelesaikan masalah matematika dengan baik (Sari \& Suherman, 2018).

Pemahaman konsep adalah kompetensi siswa yang menunjukkan dalam memahami kosep dalam melakukan prosedur (Algoritma) yang tertata dan tersusun secara sistematis, secara luwes, akurat, efesien, dan tepat. Sehingga membutuhkan pemikiran yang tinggi (Septian et al., 2020). Sehingga kemampuan pemahaman konsep matematis yang dimiliki menjadikan siswa lebih berfikir kritis dalam memecahkan masalah, dan mengatasinya dengan tenang dan tersusun antar konsep. Akan tetapi, kemampuan pemahaman konsep matematis bukan hanya sekedar mengaitkan antar konsep dari yang satu ke yang lainnya. Tetapi juga mampu mengungkapkan kembali kedalam bentuk yang lebih sederhana sehingga lebih mudah dipemahami dan dimengerti.

Adapun indikator kemampuan pemahaman konsep matematis (1) menyatakan ulang sebuah konsep, (2) mengklasifikasi objek menurut sifat tertentu sesuai dengan konsepnya, (3) memberikan contoh dan bukan contoh dari suatu konsep, (4) menyajikan konsep dalam berbagai bentuk representasi matematis, (5) mengembangkan syarat perlu atau syarat cukup dari suatu konsep, (6) menggunakan, memanfaatkan, dan memilih prosedur tertentu, (8) mengaplikasikan konsep atau algoritma pemecahan masalah (Sabon \& Astuti, 2020).

Akan tetapi, pentingnya kemampuan pemahaman konsep tidak sejalan dengan kualitas kemampuan pemahaman konsep yang sesungguhnya. Kemampuan pemahaman konsep masih tergolong rendah. Rendahnya kemampuan pemahaman konsep disebabkan karena ketidakmampuan pemecahan suatu masalah dan kurangnya pemahaman konsep dasar matematika.

Penelitian yang dilaksanakan di SMP Negeri 2 Kalianda, dimana metode belajar matematika terlalu monoton, terpaku pada guru dalam penyampaian materi pembelajaran, masih 
terpaku terhadap konsep yang terdapat pada buku, dan kurangnya pengadaan variasi dalam pembelajaran yang menyebabkan siswa cepat bosan dan kurangnya kemandirian siswa yang mengakibatkan rendahnya kemampuan pemahaman konsep matematis siswa.

Penyebab siswa kesulitan belajar matematika yaitu kurangnya daya tarik terhadap pembelajaran matematika yang hanya berfokus menghafalkan rumus matematika sehingga menyebabkan rendahnya kemampuan pemahaman (Farida, 2015). Hal ini menyebabkan siswa masih mengalami kesulitan karena sebagian besar kurang menguasai konsep matematis. Oleh karena itu, kemampuan pemahaman konsep matematis merupakan aspek terpenting pada pembelajaran agar dapat meningkatnya hasil belajar siswa.

Hal ini tampak nyata dari data yang di dapat di lapangan bahwasannya hasil nilai uji coba pra penelitian yang dilakukan oleh penulis di SMP Negeri 2 Kalianda, menunjukkan bahwa nilai rata-rata siswa masib dibawah Kriteria Ketuntasan Minimal (KKM) yaitu 70.

Selain dari hasil uji pra penelitian, didapatkan juga hasil wawancara oleh salah satu guru bahwa kebanyakan siswa menganggap pelajaran matematika adalah pelajaran yang sulit, menegangkan dan membosankan. Model yang digunakan oleh guru pun masih menggunakan model pembelajaran konvensional dengan metode ceramah, tanya jawab, serta pemberian tugas. Model pembelajaran konvensional hanya berpusat kepada guru yang menjelaskan sehingga mengakibatkan siswa menjadi sangat pasif dan tidak berkembang. Selain itu juga, bahan ajar yang digunakan masih terpaku terhadap buku dan kurangnya variasi sehingga menimbukan kesan yang kurang menyenangkan bagi siswa dalam belajar. Berdasarkan masalah yang diperoleh wajar saja jika kemampuan pemahaman konsep matematis siswa masih rendah.

Dari uraian tersebut kemampuan pemahaman konsep mampu ditingkatkan dengan menerapkan metode pembelajaran yang kreatif seperti model pembelajaran Rotating Trio Exchange (RTE).

Rotating Trio Exchange (RTE) adalah pembelajaran kelompok. Adapun yang mencirikan dari model pembelajaran ini yakni dibagi menjadi tiga bagian yaitu bagian Rotating, Trio dan Exchange. Rotating merupakan suatu langkah yang dilakukan secara berotasi, Trio merupakan kelompok yang terdiri dari tiga anggota, dan Exchange merupakan pergantian kelompok karena perpindahan anggota kelompok yang dilakukan secara Rotating atau Rotasi (Sabrun, 2017).

Menurut Isjoni, model pembelajaran Rotating Trio Exchange (RTE) adalah pembelajaran kelompok yang terdiri dari tiga peserta didik tiap kelompok yang arahkan agar dapat melihat kanan dan kiri dari kelompok lain. Tiap kelompok diberikan pertanyaan untuk didiskusikan. Setelah berdiskusi, siswa diberikan penomoran pada masing-masing anggota yang terdiri dari penomoran 0,1 , dan 2. Aturan 
penomoran yaitu, untuk siswa yang bernomor 1 dapat berpindah kekelompok lain searah jarum jam, untuk bernomor 2 dapat berpindah kesebalikan arah jarum jam, dan untuk bernomor 0 konsisten diam ditempat. Hal ini dapat menjadikan kelompok Trio baru yang kemudian diberi soal berbeda dengan tipe soal yang meningkat dari sebelumnya. Lakukan perputaran kembali seperti sebelumnya sebanyak pertanyaan yang disiapkan (Isjoni, 2013). Dengan demikian, diharapkan siswa saling bekerja sama pada saat proses pembelajaran sehingga selain siswa mendapatkan penjelasan dari guru, siswa juga dapat menjelaskan tambahan dari teman sekelompoknya.

Menurut I Md Dyatma Dipayana, I Gst. Ngr. Japa, I Md Suarjana bahwa hasil belajar siswa dengan menerapkan model pembalajaran Rotating Trio Exchange memiliki kriteria tinggi dibandingkan model pembelajaran konvensional (Dipayana et al., 2014). Sependapat Erna Isfayani, Rahma Johar, Said Munzir bahwa terdapat peningkatan terhadap kemampuan koneksi matematis siswa dengan menerapkan model pembelajaran Rotating Trio Exchange (RTE) dibandingkan model pembelajaran konvensional (Isfayani et al., 2018). Sama halnya yang dikatakan Amran Yahya, Nur Wahidah Bakri bahwa menerapan model pembelaran Rotating Trio Exchange (RTE) dapat meningkatnya keaktifan pembelajaran siswa yang bisa dilihat dari hasil belajar (Yahya \& Bakri, 2020).

Oleh sebab itu, dengan menerapkan model pembelajaran Rotating Trio Exchange
(RTE) bisa membuat siswa lebih tertarik oleh pembelajaran matematika dan tentunya tidak bosan dalam proses belajar.

Penelitian ini bertujuan untuk mengetahui apakah ada peningkatan kemampuan pemahaman konsep matematis dengan menerapkan model pembelajaran model pembelajaran Rotating Trio Exchange (RTE).

\section{METODE}

Penelitian ini dilakukan di SMP Negeri 2 Kalianda tahun ajaran 2020/2021, dengan menggunakan pendekatan kuantitatif, yaitu pengujiannya menggunakan statistik tertentu guna menguji teori yang berkaitan dengan variabel. Peneliti menggunakan metode eksperimen semu (Quasi Experiment Design). Responden yang digunakan yaitu dua kelas, kelas kontrol dan kelas eksperimen.

Populasi dalam penelitian ini yaitu siswa kelas VIII SMP Negeri 2 Kalianda.Teknik sampel yang digunakan yaitu Cluster Random Sampling, dilakukan dengan acak menggunakan cara seperti undian. Sampel yang diperoleh dalah kelas VIII A selaku kelas eksperimen yang menerapkan model pembelajaran Rotating Trio Exchange dan kelas VIII C selaku kelas kontrol dengan model pembelajaran konvensional.

Teknik pengambilan data yang dilakukan yaitu observasi, dokumen dan tes. Instrument yang terapkan ialah tes kemampuan pemahaman konsep siswa. Tes diberikan kepada siswa diawal (Pretest) dan diakhir (Posttest) berupa soal 
uraian kemampuan pemahaman konsep matematis.

Analisis yang digunakan dari perolehan tes yang telah dilakukan siswa dengan model pembelajaran Rotating Trio Exchange (RTE) yakni perbandingan hasil Pretest dan Posttest pada soal kemampuan pemahaman konsep matematis. Uji prasyarat analisis pada uji normalitas gain menggunakan uji statistik onekolmogorov-smirnov pada SPSS 25.0. Uji homogenitas gain menggunakan uji statistic Test Of Homogenitas Of Variance pada Levene's Test, pada masing-masing kriteria pengujian yaitu sig $>\alpha$ dengan $\alpha=0,05$ dapat disimpulkan bahwa $H_{0}$ diterima. Setelah melakukan pengujian tersebut dapat dilakukan dengan uji perbedaan rata-rata hasil dan ngain menggunakan uji Independen Sample t-test.

\section{HASIL}

Hasil tes kemampuan pemahaman konsep matematis pada penelitian ini adalah hasil dari perolehan Pre-test dan Post-test pada kelas VIII A yang menggunakan model pembelajaran Rotating Trio Exchange (RTE) dan VIII C yang menggunakan model pembelajaran Konvensional. Uji analisis dilakukan untuk mengetahui perbandingan pretest dan posttest siswa pada model pembelajaran Rotating Trio Exchange (RTE) dan model pembelajaran konvensional. Berikut data deskripsi kemampuan pemahaman konsep matematis.
Tabel 1 data deskripsi pretest kemampuan pemahaman konsep matematis

\begin{tabular}{ccc}
\hline & Eksperimen & Kontrol \\
\hline$N$ & 30 & 30 \\
\hline$X \max$ & 85 & 85 \\
\hline$X \min$ & 15 & 15 \\
\hline $\bar{x}$ & 54,5 & 46,8 \\
\hline$S$ & 18,9 & 19,4 \\
\hline
\end{tabular}

Berdasarkan tabel 1 di atas menunjukkan bahwa nilai tertinggi pretest adalah 85 dan terendah adalah 15. Sedangkan untuk rata-rata kelas eksperimen adalah 54,5 dengan standar devisiasi 18, 9 dan kelas kontrol adalah 46,8 dengan standar devisiasi 19,4.

Tabel 2 data deskripsi posttest kemampuan pemahaman konsep matematis

\begin{tabular}{cll}
\hline & Eksperimen & Kontrol \\
\hline$N$ & 30 & 30 \\
\hline$X \max$ & 100 & 85 \\
\hline$X \min$ & 65 & 60 \\
\hline $\bar{x}$ & 81,7 & 73,7 \\
\hline$S$ & 10,8 & 9,3
\end{tabular}

Tabel 2 adalah hasil nilai kemampuan pemahaman konsep matematis setela dilakukan penelitian. Nilai tertinggi posttest adalah 100 dan terendah adalah 60 . Sedangkan untuk rata-rata kelas eksperimen 81,7 dengan standar devisiasi 10,8 dan kelas kontrol adalah 73,7 dengan standar devisiasi 9,3. Setelah diperoleh nilai dari pretest dan posttest maka selanjutnya uji peningkatan (N-gain) untuk mengetahui perbandingan antara dua kelas yang diberi perlakuan berbeda. 
Tabel 3 deskripsidata $\mathrm{N}$-gain konsep pemahaman kemampuan matematis siswa

\begin{tabular}{lcc}
\hline \multicolumn{3}{c}{$N$-gain } \\
\hline & Kontrol & Eksperimen \\
\hline$N$ & 30 & 30 \\
\hline$X \max$ & 0,71 & 1,00 \\
\hline$X \min$ & 0,14 & 0,13 \\
\hline $\bar{x}$ & 0,49 & 0,6 \\
\hline$S$ & 0,13 & 0,2 \\
\hline$V a r$ & 0.02 & 0,04 \\
\hline
\end{tabular}

Nilai N-gain konsep pemahaman kemampuan matematis yang diperoleh dilihat table 3 di atas yang menunjukkan bahwa dari 30 siswa nilai tertinggi $\mathrm{N}$-gain adalah 1,00 dan terendah adalah 0,13 . Sedangkan untuk rata-rata kelas eksperimen adalah 0,6 dengan standar devisiasi 0,2 dan varians 0,04. Rata-rata kelas kontrol adalah 0,49 dengan standar devisiasi 0,13 dan varians 0,02 .

Tabel 4 merupakan hasil perhitungan uji normalitas $\mathrm{N}$-gain dengan menggunakan SPSS.25 pada uji Kolmogorov-Smirnov. Jika $p$-value $>\alpha(\alpha=0,05)$ berarti data dari hasil perhitungan $\mathrm{N}$-gain berdistribusi normal.

Tabel 4 Uji Normalitas N-gain

\begin{tabular}{lll}
\hline \multicolumn{3}{c}{ Kolmogorov-Smirnov } \\
\hline \multirow{2}{*}{ Sig } & Kontrol & Eksperimen \\
\cline { 2 - 3 } & 0,124 & 0,200 \\
\hline
\end{tabular}

Berdasarkan table 4 di atas bahwa nilai Sig. kelas eksperimen yaitu 0,200 menunjukkan hasil lebih dari $\alpha=0,05$ maka berdistribusi normal. Nilai Sig. kelas kontrol yaitu 0,124 menunjukkan hasil lebih dari $\alpha=0,05$ maka berdistribusi normal. Ketika uji normalitas telah dilakukan, maka selanjutnya uji homogenitas.
Tabel 5 Uji Homogenitas N-gain

\begin{tabular}{cc}
\hline \multicolumn{2}{c}{ Homogeneity of Variances } \\
\hline \multirow{2}{*}{ Ngain } & Sig. \\
\cline { 2 - 2 } & 0,066 \\
\hline
\end{tabular}

Berdasarkan tabel 5 di atas bahwa uji homogenitas $\mathrm{N}$-gain menggunakan uji statistik Homogeneity of Variances pada Levene's Test. Jikap-value $>\alpha \quad(\alpha=0,05) \quad$ maka $H_{0}$ diterima yang berarti data hasil perhitungan $\mathrm{N}$ gain tersebut bersifat homogen yaitu sampel berasal dari populasi yang memiliki variansi yang sama. Hasil Sig. yang diperoleh yaitu 0,066 menunjukkan hasil lebih dari $\alpha=0,05$ maka $H_{0}$ diterima berarti data bersifat homogen. Untuk melihat perbedaan rata-rata pada peningkatan konsep pemahaman kemampuan matematis siswa dengan melakukan uji Independen Sampel t-test.

Tabel 6 Uji Perbedaan Rata-rata $N$-Gain Kemampuan Pemahaman Konsep Matematis

\begin{tabular}{lcc}
\hline \multicolumn{1}{c}{ Kelas } & $\begin{array}{c}\text { Sig. }(2- \\
\text { Tailed) }\end{array}$ & Simpulan \\
\hline Kontrol & 0,010 & \multirow{2}{*}{$H_{0}$ ditolak } \\
\cline { 1 - 2 } Eksperimen & 0,010 & \\
\hline
\end{tabular}

Berdasrkan tabel 3 menunjukkan bahwa rata-rata uji percobaan $\mathrm{N}$-gain konsep pemahaman kemampuan matematis dengan nilai sig. (2-tailed) memperoleh hasil 0,010. Hal ini menunjukkan bahwa nilai sig. $(2-$ tailed $)<$ taraf signifikansi $(\alpha=0,05), \quad$ maka $H_{0}$ ditolak. Jika disimpukan bahwa didapatkan perbedaan rata-rata $\mathrm{N}$-gain konsep pemahaman matematis siswa kelas eksperimen melalui model pembelajaran RTE (Rotating Trio Exchange) 
dengan kelas kontrol yang menerapkan model pembelajaran konvensional.

\section{PEMBAHASAN}

Dari hasil penelitian didapatkan bahwa nilai pretest kemampuan pemahaman konsep matematis tidak jauh berbeda secara signfikansi. Dapat diketahui hasil standar devisiasi kelas kontrol lebih besar daripada kelas eksperimen. Hal ini menunjukkan bahwa kemampuan pemahaman konsep matematis kelas kontrol yang menerapkan model pembelajaran konvensional lebih menyebar dari kelas eksperimen yang menerapkan model Rotating Trio Exchange (RTE).

Setelah dilakukannya penelitian, baik kelas eksperimen maupun kelas kontrol sesuai dengan adanya langkah-langkah model pembelajaran RTE (Rotating Trio Exchange) dan model pembelajaran konvensional, hasil posttest kemampuan pemahaman konsep matematis membuktikan bahwa nilai rata-rata dan standar devisiasi kelas eksperimen yang menggunakan model pembelajaran Rotating Trio Exchange (RTE) lebih tinggi daripada kelas kontrol yang menggunakan model pembelajaran konvensional, maka model pembelajaran Rotating Trio Exchange (RTE) lebih baik dibandingkan model pembelajaran konvensional.

Sejalan dengan penelitian yang dilakukan oleh Purwanti (2013), mengatakan bahwa kemampuan pemahaman konsep matematis siswa yang menerapkan model pembelajaran Rotating Trio Exchange (RTE) lebih baik dibandingkan dengan model pembelajaran konvensional. Dapat dilihat dari pencapaian nilai rata-rata yang diperoleh berdasarkan indikator pemahaman konsep matematis siswa yakni rata-rata pencapaian indikator pemahaman konsep matematis yang menerapkan model RTE (Rotating Trio Exchange) lebih tinggi dari siswa yanga menerapkan model konvensional (Purwanti et al., 2013).

Peningkatan kemampuan pemahaman konsep matematis siswa melalui model pembelajaran RTE (Rotating Trio Exchange) dilihat dari perolehan nilai rata-rata pretest dan posttest. Perolehan nilai rata-rata test awal (Pretest) sebesar 54,5 dan ketika tes akhir (Posttest) perolehan sebesar 81,7. Hal tersebut menunjukkan bahwa terdapat peningkatan kemampuan pemahaman konsep matematis secara signifikan antara nilai rata-rata sebelum dan sesudah diberikannya perlakuan dengan menggunakan model pembelajaran RTE (Rotating Trio Exchange). Setelah itu dilihat dari perhitungan statistik yaitu perhitungan N-gain dan uji Independen Sampel t-test diperoleh signifikan (2-tailed) sebesar 0,010. Hal ini menunjukkan bahwa sig. $(2-$ tailed $)<$ taraf signifikansi $(\alpha=0,05), \quad$ maka $H_{0}$ ditolak. Hal ini dapat dinyatakan bahwa terjadi peningkatan yang signifikan nilai rata-rata kedua kelas tersebut, maka dapat disimpulkan bahwa kemampuan pemahaman konsep matematis siswa ketika menggunakan model pembelajaran Rotating Trio Exchange (RTE) 
mengalami peningkatan yang signifikan. Berdasarkan pemaparan di atas dapat di simpulkan bahwa penerapan model pembelajaran Rotating Trio Exchange (RTE) dapat meningkatkan kemampuan pemahaman konsep matematis siswa.

\section{Model pembelajaran Rotating Trio} Exhange (RTE) lebih baik dari model pembelajaran konvensional. Hal ini disebabkan karena model pembelajaran RTE lebih menekankan pengetahuan siswa dan menjadikan siswa lebih aktif dalam belajar serta menjawab soal dengan cepat. Siswa juga termotivasi dalam belajar sehingga mampu meningkatkan pemahaman konsep matematis yang dilihat dari hasil belajar siswa. Penerapan model pembelajaran RTE memberikan respon positif terhadap pembelajaran matematika dengan mengatakan bahwa model ini dapat membantu memahami materi dalam pembelajaran dan mengasah pemikiran siswa untuk memecahkan masalah ketika diberikan soal.

Menurut Silberman model pembelajaran Rotating Trio Exchange (RTE) merupakan cara yang dilakukan siswa untuk menguasai dan memperdalam interprestasi siswa dengan memecahkan masalah yang diberikan untuk didiskusikan dengan teman kelompoknya, membantu guru mengubah pola belajar siswa yang efektif dengan menjadikan siswa berperan aktif dan mendorong siswa untuk saling bekerja sama (Heliyandari et al., 2018)

Model pembelajaran RTE (Rotating Trio Exchange) meningkatkan kemampuan pemahaman konsep matematis siswa. Adapun yang mempengaruhi kemampuan pemahaman konsep matematis yaitu sistematisasi dari sajian materi, karena materi merupakan pengetahuan yang akan diserap oleh siswa dalam proses pembelajaran. Kemampuan pemahaman konsep matematis mempunyai indikator pencapaian yaitu: (1) menyatakan ulang sebuah konsep, (2) mengklasifikasi objek-objek menurut sifat-sifat tertentu (sesuai dengan konsepnya), (3) memberi contoh dan non contoh dari konsep, (4) menyajikan konsep dalam berbagai bentuk representasi matematis, (5) mengembangkan syarat perlu dan syarat cukup suatu konsep, (6) menggunakan, memanfaatkan, dan memilih prosedur atau operasi tertentu, dan (7) mengaplikasikan konsep atau algoritma pemecahan masalah (Kesumawati, 2008)

\section{KESIMPULAN}

Berdasarkan hasil dari analisis dan pembahasan, maka didapatkan kesimpulan bahwaterdapat peningkatan pemahaman konsep matematis siswa dengan model pembelajaran RTE (Rotating Trio Exchange). Hal ini dilihat dari perbedaan rata-rata $\mathrm{N}$-gain kemampuan pemahaman konsep matematis siswa pada kelas eksperimen yang menerapkan model pembelajaran Rotating Trio Exchange (RTE) lebih tinggi dari pada kelas kontrol yang menerapkan model pembelajaran konvensional. Sehingga model pembelajaran Rotating Trio Exchange (RTE) lebih baik dibandingkan dengan model pembelajaran konvensional. 


\section{UCAPAN TERIMA KASIH}

Alhamdulillah Waa Syukurillah, saya mengucapkan terima kasih untuk pengarahan, dukungan serta bantuan dari beberapa pihak kepada Kepala Sekolah SMP Negeri 2 Kalianda, Bapak Yamin, S.Pd. yang telah memberikan izin penelitian dan Guru mata pelajaran MatematikaBapak Syahrial, S.Pd, yang menyempatkan waktu dan memberi masukan. Serta semua Pihak Jurnal yang sudah memberikan izin serta membantu kelancaran penulisan.

\section{DAFTAR PUSTAKA}

Dipayana, I. M. D., Japa, I. G. N., \& I Md. Suarjana. 2014. Pengaruh Strategi Pembelajaran Rotating Trio Exchange (RTE) Terhadap Hasil Belajar Matematika. Jurnal Mimbar PGSD Universitas Pendidikan Ganesha, 2(1).

Farida, F. 2015. Mengembangkan Kemampuan Pemahaman Konsep Peserta Didik Melalui Pembelajaran Berbasis VCD. AlJabar:Jurnal Pendidikan Matematika, 6(1), 25-32.

Heliyandari, Y., Rohmadi, M., \& Yuliani, H. 2018. Penerapan Model Pembelajaran Kooperatif Tipe Rotating Trio Exchange terhadap Keterampilan Kooperatif dan Hasil Belajar Siswa pada Materi Momentum dan Implus. Jurnal Penelitian Pembelajaran Fisika, 9(1), 29.

Isfayani, E., Johar, R., \& Munzir, S. 2018. Peningkatan Kemampuan Koneksi Matematis dan Self-Efficacy Siswa Melalui Model Pembelajaran Kooperatif Tipe Rotating Trio Exchange (RTE). Jurnal Elemen, 4(1), 91.
Isjoni, I. 2013. Cooperative Learning Efektifitas Pembelajaran Kelompok ( 7 th edn). Alfabeta.

Kesumawati, N. 2008. Pemahaman Konsep Matematik dalam Pembelajaran Matematika.Semhas Matematika Dan Pendidikan Matematika, 2, 234.

Purwanti, E., Noer, S. H., \& Amelis Djalil. 2013. Pengaruh Penerapan Model Pembelajaran Rotating Trio Excahange Terhadap Pemahaman Konsep Matematis Siswa. Pendidikan Matematika, Universitas Lampung, 9.

Sabon, Z. A. K. W., \& Astuti, Y. D. 2020. Analisis Kemampuan Pemahaman Konsep Matematis Siswa SMP pada Materi Relasi dan Fungsi. Prosiding Sendika, 6(2), 114.

Sabrun. 2017. Penerapan Model Rotating Trio Exchange untuk Meningkatkan Hasil Belajar Matematika Pokok Bahasan Lingkaran pada Siswa Kelas VIII SMP Muhammadiyah Mataram Tahun Pelajaran 2016/2017. Jurnal Ilmiah Mandala Education, 3(2), 267.

Sari, H., \& Suherman. 2018. Pengaruh Penerapan Model Pembelajaran Kooperatif Tipe Think Talk Write (TTW) terhadap Pemahaman Konsep Matematika Peserta Didik Kelas XI MIA SMAN 2 Pariaman. Jurnal Edukasi Dan Penelitian Matematika, 7(4).

Septian, A., Agustina, D., \& Maghfirah, D. 2020.Model Pembelajaran Kooperatif Tipe Student Teams Achievement Devision (STAD) untuk Meningkatkan Pemahaman Konsep Matematika. Mathema Journal, 2(2), 11.

Yahya, A., \& Bakri, N. W. 2020.Pembelajaran Kooperatif Tipe Rotating Trio Exchange untuk Meningkatkan Aktivitas dan Hasil Belajar Matematika Siswa. Jurnal Analisa, 6(1), 78. 